\title{
GAMBARAN PENGETAHUAN IBU RUMAH TANGGA TENTANG TANDA DAN GEJALA INFEKSI HIV/AIDS WILAYAH HAJI UNGAR RT.001/RW.III KELURAHAN TANJUNG AYUN SAKTI KECAMATAN BUKIT BESTARI TANJUNGPINANG 2014 (Overview of Housewife Knowledge, about HIVIAIDS Infection sign and symptoms in Haji Ungar Area RT.001/RW.III Tajung Ayun Sakti Village, Bukit Bestari Distric Tanjungpinang at 2014)
}

\author{
Dewi Pusparianda, Dede Dwika Wamardhana \\ PoltekkesKemenkesTanjungpinang \\ email:dewipusparianda@yahoo.co.id
}

\begin{abstract}
The number HIV incident in Tanjungpinang keep rising in 2013, the rising of the incident reach to 244 cases (the rising occurring to $42 \%$ in 2012). Some groups think the infection of HIV/AIDS is obtained by prostitute, homosexual, and so on. The infection also obtained by housewife and children. In early research, showed that 3 housewife didn't know the signs and symptomps of the infection. It's a basic to do a research "Overview of housewife knowledges about signs and symptomps infection of HIV/AIDS in district Haji Ungar RT.001/RW.III Kelurahan Tanjung Ayun Sakti Kecamatan Bukit Bestari Tanjungpinang". The purpose of this research was to know the overview of housewife knowledge about signs and symptomps of HIV/AIDS in district Haji Ungar RT. 001/RW. III Kelurahan Tanjung Ayun Sakti Kecamatan Bukit Bestari Tanjungpinang. The study was done in 12 June 2014. The Number of samples of this research was 30 housewives. The Sample technique in this research was randomize. The instrument used in this research was questionaire. The result Obtained that the housewife knowledges in districk Haji Ungar RT. 001/RW. III against the signs of the symptomps infection HIV/AIDS in district Haji Ungar RT. 001/RW. III Kelurahan Tanjung Ayun Sakti Kecamatan Bukit Bestari was great (86\%). Housewife knowledges was great, maybe its because of good introduction about that problem. Level of education, experience, or good socio-cultural towards it will make housewife can recognize the problems. It was recommended that the housewife could get more knowledge and health expecially about body resistance. Housewife also recommended to do health checking in public health services.
\end{abstract}

Keywords: house knowledges, signs and symptomps, HIV/AIDS

\begin{abstract}
Abstrak: Peningkatan angka kejadian HIV di Tanjungpinang terus meningkat, pada tahun 2013, peningkatan angka kejadian HIV mencapai 224 kasus (terjadi peningkatan 42\% dari tahun 2012). Sebagian kelompok berfikir penularan HIV/AIDS banyak di dapat oleh PSK, homoseksual, dan sebagainya. Penyebaran HIV/ AIDS juga di dapat oleh ibu rumah tangga dan anak-anak. Dalam penelitian awal, didapat 3 ibu rumah tangga tidak mengetahui tanda dan gejala dari infeksi HIV. Hal tersebut mendasari perlunya diadakan penelitian "Gambaran Pengetahuan Ibu Rumah Tangga Tentang Tanda dan Gejala Infeksi HIV/AIDS Wilayah Haji Ungar RT. 001/RW. III Kelurahan Tanjung Ayun Sakti Kecamatan Bukit Bestari Tanjungpinang". Tujuan penelitian ini adalah untuk mengetahui gambaran pengetahuan ibu rumah tangga tentang tanda dan gejala infeksi HIV/AIDS di wilayah Haji Ungar RT. 001/RW. III Kelurahan Tanjung Ayun Sakti Kecamatan Bukit Bestari Tanjungpinang. Desain penelitian ini penelitian deskriptif. Penelitian dilakukan di wilayah haji ungar RT. 001/RW. III Kelurahan Tanjung Ayun Sakti Kecamatan Bukit Bestari Tanjungpinang. Waktu penelitian dilaksanakan pada tanggal 12 juni 2014. Jumlah sampel pada penelitian ini ibu rumah tangga yang berjumlah 30 sampel. Teknik sampling dalam penelitian menggunakan teknik simple random sampling. Instrumen yang digunakan dalam penelitian ini adalah Kuesioner. Hasil penelitian didapat bahwa
\end{abstract}


pengetahuan ibu rumah tangga di wilayah haji ungar RT. 001/RW. III terhadap tanda dan gejala infeksi HIV/ AIDS di Wilayah Haji Ungar Kelurahan Tanjung Ayun Sakti Kecamatan Bukit Bestari yaitu baik (86\%). Kesimpulan dan Saran: Pengetahuan yang dimiliki ibu rumah tangga yaitu baik, dapat dikarenakan pengenalan yang baik terhadap permasalahan tersebut. Tingkat pendidikan, pengalaman, ataupun sosial budaya yang baik terhadap permasalahan tersebut akan membuat ibu rumah tangga dapat mengenali masalah tersebut. Disarankan kepada ibu rumah tangga untuk dapat meningkatkan pengetahuan dan kesehatan terutama kesehatan mengenai system kekebalan tubuh. Ibu juga disarankan untuk melakukan pengecekan kesehatan di fasilitaskesehatan yang tersedia.

Kata Kunci: pengetahuan ibu rumah tangga, tanda dan gejala, HIV/AIDS

HIV/AIDS (Human Immuno deficiency Virus/ Acquired Immune Deficiency Syndrome) merupakan masalah kesehatan di dunia sejak tahun 1981, penyakit ini berkembang secara pandemik. Obat dan Vaksin untuk mengatasi masalah tersebut belum ditemukan, yang dapat mengakibatkan kerugian tidak hanya di bidang kesehatan tetapi juga di bidang sosial, ekonomi, politik, budaya dan demografi (Depkes RI 2006).

Kasus AIDS yang pertama kali sekali muncul di Amerika Serikat pada bulan Mei tahun 1981. Virus HIV pertama kali ditemukan di Perancis pada tahun 1983 oleh Dr. Luc Montagnier dan menjangkit jutaan pria, wanita, dan anak-anak yang ada di dunia ini. Kasus pertama penyakit ini terjadi dikalangan kaum homoseksual (suatu prilaku seksual yang menyimpang dengan sesama jenis, dalam hal ini adalah pria) pria di negara industri tinggi yang kemudian menyebar ke jangkauan yang lebih jauh lagi. Epidemi HIV/ AIDS kini telah meluas dan menjadi masalah internasional, pertambahan kasus yang cepat dan penyebarannya ke berbagai negara telah menimbulkan keresahan dan keprihatinan di seluruh dunia (Julianto, 2004).

Menurut World Health Organization (WHO) dilaporkan bahwa pada tahun 2011 terdapat 3,5 juta orang di Asia Tenggara hidup dengan HIV/AIDS. Beberapa Negara seperti Myanmar, Nepal dan Thailand menunjukkan Tren penurunan untuk infeksi baru HIV, hal ini dihubungkan salah satunya dengan diterapkannya program pencegahan HIV/AIDS melalui program Condom use 100 persen (CUP). Trend kematian yang disebabkan oleh AIDS antara tahun 2001 sampai 2010 berbeda disetiap bagian Negara. Di Eropa Timur dan Asia Tengah sejumlah orang meninggal karena AIDS meningkat dari 7.800 menjadi 90.000, di Timur Tengah dan Afrika Utara meningkat dari 22.000 menjadi 35.000, di Asia Timur juga meningkat dari 24.000 menjadi 56.000 (WHO, Progress Report 2011).
Indonesia saat ini mengalami epidemi ganda, yaitu infeksi Human Immunodeficiency Virus HIV dan penggunaan narkoba dengan jarum suntik (Sirait, 2006). Sejak tahun 1999 penggunaan narkoba dengan jarum suntik telah menjadi pendorong utama peningkatan kasus epidemi HIV/AIDS di beberapa wilayah di Indonesia, termasuk Jakarta, Jawa Barat, dan Bali. Infeksi HIV/AIDS menular dari para pengguna narkoba suntik (penasun) kepada mitra mereka yang bukan merupakan pengguna narkoba suntik (non penasun) dan kepada para pekerja seks. HIV/AIDS dapat menular melalui hubungan seks yang tidak aman, penggunaan jarum suntik yang tidak steril secara bergantian, transfusi darah dengan orang yang terkena HIV/AIDS, dan penularan ibu ke bayi yang dikandungnya (Depkes, 2006).

Peningkatan akan kasus penderita HIV di Provinsi Kepulauan Riau terus meningkat, dari tanggal 1 Januari 2010 sampai 31 Desember 2010 peningkatan kasus HIV mencapai 621 kasus. Peningkatan akan angka kejadian HIV terus terjadi dilihat dari tanggal 1 Januari 2011 sampai 31 Desember 2011 angka kejadian HIV mencapai 704 kasus (terjadi peningkatan $11,8 \%$ dari tahun 2010), pada tanggal 1 Januari 2012 sampai dengan 31 Desember 2012 angka kejadian HIV mencapai 852 kasus (terjadi peningkatan 17,4\% dari tahun 2011) (Dinkes Provinsi Kepri, 2012).

Peningkatan akan angka kejadian HIV di Tanjungpinang terus meningkan pada tahun 2010 mencapai 122 kasus, pada tahun 2011 angka kejadian HIV mencapai 133 kasus (terjadi peningkatan 8,2\% dari tahun 2010), dan pada tahun 2012 angka kejadian HIV mencapai 130 kasus (terjadi penurunan 2,3\% dari tahun 2011), dan pada tahun 2013 terjadi peningkatan kembali angka kejadian HIV mencapai 224 kasus (terjadi peningkatan $42 \%$ dari tahun 2012) (Dinkes Kota Tanjungpinang, 2013).

Sebagian kelompok berfikir bahwa penularan HIV/AIDS banyak di dapat oleh kaum lelaki, PSK, 
homoseksual, dan sebagainya. Penyebaran HIV/ AIDS juga di dapat oleh ibu rumah tangga dan anakanak, dalam hal ini ibu rumah tangga yang hanya berprofesi di rumah kemungkinan kurang memahami mengenai HIV/AIDS, bahkan tidak mengetahui apa yang akan dilakukan jika mengalami gejala AIDS tersebut.

Dalam hal ini peneliti melakukan survei awal dengan wawancara kepada 3 ibu rumah tangga di wilayah Haji Ungar RT. 01/RW. III untuk mengetahui sejauhmana pemahaman ibu tentang HIV/ AIDS. Setelah dilakukan survei awal tersebut didapat 3 ibu tersebut tidak mengetahui mengenai tanda dan gejala AIDS serta upaya apa yang akan dilakukannya. Dari data awal berikut peneliti tertarik melakukan penelitian mengenai gambaran pengetahuan ibu rumah tangga tentang tanda dan gejala AIDS

\section{BAHAN DAN METODE}

Desain penelitian ini penelitian deskriptif dalam penelitian ini ingin mengetahui gambaran pengetahuan ibu rumah tangga tentang tanda dan gejala AIDS guna untuk menentukan upaya apa yang akan dilakukan jika terdapat tanda dan gejala AIDS.

Penelitian ini telah dilaksanakan di wilayah Haji Ungar RT.001/RW.III Kelurahan Tanjung Ayun Sakti Kecamatan Bukit Bestari Tanjungpinang tahun 2014.Penelitian telah dilaksanakan 3 hari, dimulai pada tanggal 12 Juni 2014 sampai dengan 14 Juni 2014.

Populasi dalam penelitian ini adalah seluruh ibu rumah tangga yang bertempat tinggal di wilayah haji ungar RT.001/RW.III Kelurahan Tanjung Ayun Sakti Kecamatan Bukit Bestari Tanjungpinang dengan jumlah 59 orang. Jumlah sampel pada penelitian ini adalah semua ibu rumah tangga yang bertempat tinggal di wilayah haji ungar RT.001/ RW.III Kelurahan Tanjung Ayun Sakti Kecamatan Bukit Bestari Tanjungpinang yakni berjumlah 30 orang. Teknik sampling dalam penelitian ini menggunakan teknik simple random sampling. Instrumen penelitian yang digunakan dalam penelitian ini adalah dengan menggunakan kuesioner.

Analisis data yang digunakan dalam penelitian ini adalah analisis univariat atau analisis deskriftif. Analisis ini hanya menghasilkan distribusi frekuensi dari presentasi masing-masing variabel yang diteliti.

Dari hasil kuisioner pengetahuan ibu rumah tangga tentang tanda dan gejala AIDS akan diolah dan jika jawaban responden benar akan diberi skor
1 (satu), sedangkan jika jawaban salah akan diberi skor 0 (nol).

Kemudian dari nilai tersebut ditentukan skor total pada masing-masing responden dengan rumus: Rumus:

$\mathrm{P}=\mathrm{f} /(\mathrm{N}) \times 100 \%$

\section{Keterangan:}

$\mathrm{P}=$ Persentase

$\mathrm{F}=$ Jumlah jawaban yang benar

$\mathrm{N}=$ Jumlah soal

Dari persentase di atas, kemudian ditafsirkan ke dalam bentuk data kualitatif dengan menggunakan skala (Nursalam, 2008) Baik bila hasil: 76$100 \%$, cukup bila hasil: $56-75 \%$, Kurang bila hasil: $<56 \%$

\section{HASIL PENELITIAN}

Tabel 1. Distribusi Frekuensi Ibu Rumah Tangga Berdasarkan Umur di Wilayah Haji Ungar RT. 001/RW. III Tanjungpinang

\begin{tabular}{cccc}
\hline No & Umur & Frekuensi & $\begin{array}{c}\text { Persentase } \\
(\%)\end{array}$ \\
\hline 1 & $23-28$ & 3 & $10 \%$ \\
2 & $29-34$ & 6 & $20 \%$ \\
3 & $35-40$ & 8 & $26,7 \%$ \\
4 & $41-46$ & 7 & $23,3 \%$ \\
5 & $47-52$ & 5 & $16,7 \%$ \\
6 & $53-58$ & 0 & $0 \%$ \\
7 & $59-64$ & 1 & $3,3 \%$ \\
\hline & Jumlah & $\mathbf{3 0}$ & $\mathbf{1 0 0 \%}$ \\
\hline
\end{tabular}

Berdasarkan tabel 1 dapat dilihat bahwa distribusi umur ibu rumah tangga kurang dari separuh adalah umur 35-40 tahun sebanyak 8 orang $(26,7 \%)$.

Tabel 2. Distribusi Frekuensi Ibu Rumah Tangga Berdasarkan Pendidikan di Wilayah Haji Ungar RT. 001/RW. III Tanjungpinang Bulan Juni 2014

\begin{tabular}{cccc}
\hline No & $\begin{array}{c}\text { Pendidikan } \\
\text { Terakhir }\end{array}$ & Frekuensi & $\begin{array}{c}\text { Persentase } \\
(\mathbf{\%})\end{array}$ \\
\hline 1 & Tidak Sekolah & 0 & $0 \%$ \\
2 & SD & 3 & $10 \%$ \\
3 & SMP & 7 & $23,3 \%$ \\
4 & SMA & 18 & $60 \%$ \\
5 & Perguruan Tinggi & 2 & $6,7 \%$ \\
\hline & Jumlah & $\mathbf{3 0}$ & $\mathbf{1 0 0 \%}$ \\
\hline
\end{tabular}

Sumber: Data Primer tahun 2014 
Berdasarkan tabel 2 dapat dilihat bahwa lebih dari separuh tingkat pendidikan terakhir ibu rumah tangga adalah SMA sebanyak 18 orang $(60 \%)$. Sedangkan sebagian kecil pendidikan terakhir ibu rumah tangga adalah tingkat perguruan tinggi sebanyak 2 orang $(6,7 \%)$.

Tabel 3. Distribusi Frekuensi Ibu Rumah Tangga Berdasarkan Informasi yang Diperoleh di Wilayah Haji Ungar RT. 001/RW. III Tanjungpinang

\begin{tabular}{|c|c|c|c|}
\hline No & $\begin{array}{c}\text { Informa si yang } \\
\text { Diperoleh }\end{array}$ & Frekuensi & $\begin{array}{c}\text { Persentase } \\
(\%)\end{array}$ \\
\hline 1 & Tidak Ada & 0 & $0 \%$ \\
\hline 2 & Keluarga/Teman & 1 & $3,3 \%$ \\
\hline 3 & $\begin{array}{c}\text { Media } \\
\text { (elektronik/cetak) }\end{array}$ & 14 & $46,7 \%$ \\
\hline 4 & Tenaga Kesehatan & 14 & $46,7 \%$ \\
\hline 5 & $\begin{array}{c}\text { Teman, Media, } \\
\text { dan Tenaga } \\
\text { Kesehatan }\end{array}$ & 1 & $3,3 \%$ \\
\hline & Jumlah & 30 & $100 \%$ \\
\hline
\end{tabular}

Sumber: Data Primer tahun 2014

Berdasarkan tabel 3 dapat dilihat bahwa distribusi berdasarkan informasi yang diperoleh kurang dari separuh adalah media dan tenaga kesehatan masing-masing sebanyak 14 orang $(46,7 \%)$. Sedangkan yang paling sedikit adalah informasi yang diperoleh dari keluarga/teman dan keluarga/teman, media, dan tenaga kesehatan, masing-masing sebanyak 1 orang $(3,3 \%)$.

Tabel 4. Distribusi Frekuensi PengetahuanIbu Rumah Tangga Tentang Pengertian HIV/AIDS di Wilayah Haji Ungar RT.001/RW. III Tanjungpinang Bulan Juni 2014

\begin{tabular}{|c|c|c|c|}
\hline No & Pertanyaan & Frekuensi & $\begin{array}{c}\text { Persentase } \\
(\%)\end{array}$ \\
\hline 1 & $\begin{array}{l}\text { HIV adalah virus } \\
\text { yang melemahkan... }\end{array}$ & 30 & $100 \%$ \\
\hline 2 & $\begin{array}{l}\text { HIV adalah } \\
\text { penyakit yang tidak } \\
\text { dapat... }\end{array}$ & 28 & $93 \%$ \\
\hline 3 & $\begin{array}{lr}\text { AIDS } & \text { adalah } \\
\text { kumpulan gejala } & \text { gtau infeksi... }\end{array}$ & 29 & $97 \%$ \\
\hline & Rata-Rata & 29 & $97 \%$ \\
\hline
\end{tabular}

Sumber: Data Primer tahun 2014

Berdasarkan tabel 4 didapatkan data bahwa gambaran pengetahuan ibu rumah tangga di Wilayah Haji Ungar RT.001/RW.III Tanjungpinang tentang Pengertian HIV/AIDS yaitu baik $(97 \%)$.
Jumlah data di atas adalah rata-rata dari subvariabel tentang pegertian HIV/AIDS yang terdiri dari 3 pertanyaan.

Tabel 5. Distribusi Frekuensi Pengetahuan Ibu Rumah Tangga Tentang Penularan Infeksi HIV/AIDS di Wilayah Haji Ungar RT.001/RW.III Tanjungpinang Bulan Juni 2014

\begin{tabular}{|c|c|c|c|}
\hline No & Pertanyaan & Frekuensi & $\begin{array}{c}\text { Persentase } \\
(\%)\end{array}$ \\
\hline 1 & $\begin{array}{l}\text { Virus HIV lebih } \\
\text { mengancam pria... }\end{array}$ & 26 & $87 \%$ \\
\hline 2 & $\begin{array}{l}\text { Bersentuhan tan gan } \\
\text { dapat... }\end{array}$ & 29 & $97 \%$ \\
\hline 3 & $\begin{array}{l}\text { Makan bersama tidak } \\
\text { dapat... }\end{array}$ & 26 & $87 \%$ \\
\hline 4 & $\begin{array}{l}\text { Berhubungan seksual } \\
\text { tanpa } \\
\text { menggunakan... }\end{array}$ & 28 & $93 \%$ \\
\hline & Rata-Rata & 27 & $91 \%$ \\
\hline
\end{tabular}

Berdasarkan tabel 5 didapatkan data bahwa gambaran pengetahuan ibu rumah tangga di Wilayah Haji Ungar RT.001/RW.III Tanjungpinang tentang penularan infeksi HIV/AIDS yaitu baik (91\%).

Jumlah data diatas adalah rata-rata dari subvariabel tentang penularan infeksi HIV/AIDS yang terdiri dari 4 pertanyaan.

Tabel 6. Distribusi Frekuensi Pengetahuan Ibu Rumah TanggaTentang Tanda dan Gejala Infeksi HIV/ AIDS di Wilayah Haji Ungar RT.001/RW.III Tanjungpinang Bulan Juni 2014

\begin{tabular}{clccc}
\hline No & Pertanyaan & Frekuensi & $\begin{array}{c}\text { Persentase } \\
(\%)\end{array}$ \\
\hline 1 & $\begin{array}{l}\text { Gejala awal yang } \\
\text { tampak... }\end{array}$ & 27 & $90 \%$ \\
2 & $\begin{array}{l}\text { TBC ad alah salah } \\
\text { satu penyakit... }\end{array}$ & 4 & $13 \%$ \\
3 & $\begin{array}{l}\text { Gejala demam yang } \\
\text { berkepanjangan... }\end{array}$ & 15 & $50 \%$ \\
\hline \multicolumn{3}{c}{ Rata-Rata } & $\mathbf{1 5}$ & $\mathbf{5 1 \%}$ \\
\hline Sumber: Data Primer tahun 2014
\end{tabular}

Berdasarkan tabel 6 didapatkan data bahwa gambaran pengetahuan ibu rumah tangga di Wilayah Haji Ungar RT.001/RW.III Tanjungpinang tentang tanda dan gejala infeksi HIV/AIDS yaitu kurang $(51 \%)$.

Jumlah data di atas adalah rata-rata dari subvariabel tentang tanda dan gejala infeksi HIV/AIDS yang terdiri dari 3 pertannyaan. 
Tabel 7. Distribusi Frekuensi Pengetahuan Ibu Rumah Tangga Tentang Upaya yang Dilakukan Bila Mengalami Tanda dan Gejala AIDS Tanjungpinang Bulan Juni 2014

\begin{tabular}{llcc}
\hline No & Pertanyaan & Frekuensi & $\begin{array}{c}\text { Persentase } \\
(\mathbf{\%})\end{array}$ \\
\hline 1 & $\begin{array}{l}\text { Melakukan tes HIV } \\
\text { sebaiknya... }\end{array}$ & 27 & $90 \%$ \\
2 & $\begin{array}{l}\text { Pergi ke pusat konsultasi } \\
\text { AIDS adalah... }\end{array}$ & 26 & $87 \%$ \\
3 & $\begin{array}{l}\text { Berterus terang dan } \\
\text { memiliki sikap terbuka... }\end{array}$ & 30 & $100 \%$ \\
\hline \multicolumn{2}{c}{ Rata-Rata } & $\mathbf{2 7}$ & $\mathbf{9 2 \%}$ \\
\hline Sumber:
\end{tabular}

Sumber: Data Primer tahun 2014

Berdasarkan tabel 7 didapatkan data bahwa gambaran pengetahuan ibu rumah tangga di Wilayah Haji Ungar RT.001/RW.III Tanjungpinang tentang upaya yang dilakukan bila mengalami tanda dan gejala AIDS yaitu baik (92\%).

Jumlah data di atas adalah rata-rata dari subvariabel tentang upaya yang dilakukan bila mengalami tanda dan gejala AIDS yang terdiri dari 3 pertanyaan.

Tabel 8. Distribusi Frekuensi Pengetahuan Ibu Rumah Tangga Tentang Pencegahan Penularan Infeksi HIV/AIDS di Wilayah Haji Ungar RT. 01/RW. III Tanjungpinang Bulan Juni 2014

\begin{tabular}{clcc}
\hline No & Pertanyaan & Frekuensi & $\begin{array}{c}\text { Persentase } \\
(\mathbf{\%})\end{array}$ \\
\hline 1 & $\begin{array}{l}\text { Hindari bergonta-ganti } \\
\text { pasangan... }\end{array}$ & 30 & $100 \%$ \\
2 & $\begin{array}{l}\text { Kondom dapat mencegah } \\
\text { pen yebaran... }\end{array}$ & 29 & $97 \%$ \\
3 & $\begin{array}{l}\text { Lebih berhati-hati memilih } \\
\text { pasangan... }\end{array}$ & 30 & $100 \%$ \\
\hline$\quad$ Rata-Rata & 30 & $99 \%$ \\
\hline
\end{tabular}

Sumber: Data Primer tahun 2014

Berdasarkan tabel 8 didapatkan data bahwa gambaran pengetahuan ibu rumah tangga di Wilayah Haji Ungar RT.001/RW.III Tanjungpinang tentang pencegahan penularan infeksi HIV/AIDS yaitu baik (99\%).

Jumlah data diatas adalah rata-rata dari subvariabel tentang pencegahan penularan infeksi HIV/ AIDS yang terdiri dari 3 pertanyaan.

Berdasarkan tabel 9 didapatkan data bahwa mayoritas pengetahuan Ibu Rumah Tangga Tentang Tanda dan Gejala Infeksi HIV/AIDS Wilayah Haji Ungar RT.001/RW.III Kelurahan Tanjung Ayun Sakti Kecamatan Bukit Bestari Tanjungpinang adalah Baik (86\%).

Jumlah data di atas adalah rata-rata dari masingmasing subvariabel tentang pengetahuan Ibu Rumah
Tabel 9. Distribusi Frekuensi Pengetahuan Ibu Rumah Tangga tentang Tanda dan Gejala Infeksi HIV/ AIDS di Wilayah Haji Ungar RT.001/RW.III Tanjungpinang Bulan Juni 2014

\begin{tabular}{|c|c|c|c|}
\hline No & Sub Variabel & Frekuensi & $\begin{array}{c}\text { Persentase } \\
(\%)\end{array}$ \\
\hline 1 & $\begin{array}{ll}\text { Pengertian } & \text { Infeksi } \\
\text { HIV/AIDS } & \end{array}$ & 29 & $97 \%$ \\
\hline 2 & $\begin{array}{l}\text { Penularan Infeksi } \\
\text { HIV/AIDS }\end{array}$ & 27 & $91 \%$ \\
\hline 3 & $\begin{array}{l}\text { Tanda dan Gejala } \\
\text { Infeksi HIV/AIDS }\end{array}$ & 15 & $51 \%$ \\
\hline 4 & $\begin{array}{lr}\text { Upaya } & \text { yang } \\
\text { Dilakukan } & \text { Bila } \\
\text { Mengalami } & \text { Tanda } \\
\text { dan Gejala AIDS }\end{array}$ & 27 & $92 \%$ \\
\hline 5 & $\begin{array}{l}\text { Pencegahan Infeksi } \\
\text { HIV/AIDS }\end{array}$ & 30 & $99 \%$ \\
\hline
\end{tabular}

Sumber: Data Primer tahun 2014

Tangga Tentang Tanda dan Gejala Infeksi HIV/ AIDS Wilayah Haji Ungar RT.001/RW.III Kelurahan Tanjung Ayun Sakti Kecamatn Bukit Bestari Tanjungpinang.

\section{PEMBAHASAN}

\section{Pengetahuan Ibu Rumah Tangga tentang Pengertian HIV/AIDS}

Berdasarkan tabel 4 didapatkan data bahwa gambaran pengetahuan ibu rumah tangga di Wilayah Haji Ungar RT.001/RW.III Tanjungpinang tentang Pengertian HIV/AIDS yaitu baik (97\%). Baiknya pengetahuan ibu rumah tangga tentang pengertian HIV/AIDS disebabkan karena faktor tingkat pendidikan dari ibu rumah tangga yang pendidikan terakhirnya adalah tingkat SMA berjumlah 18 orang (60\%), di mana sesuai dengan salah satu teori menyebutkan bahwa faktor yang mempengaruhi pengetahuan adalah tingkat pendidikan.

Menurut Notoadmodjo (2010), faktor-faktor yang dapat mempengaruhi pengetahuan antara lain adalah tingkat pendidikan yang di mana pendidikan adalah suatu usaha untuk mengembangkan kepribadian dan kemampuan di dalam dan di luar sekolah dan berlangsung seumur hidup. Pendidikan mempengaruhi proses belajar, makin tinggi pendidikan seorang makin mudah orang tersebut untuk menerima informasi. Dengan pendidikan tinggi maka seseorang akan cenderung untuk mendapatkan informasi, baik dari orang lain maupun dari media massa. Semakin banyak informasi yang masuk semakin banyak pula pengetahuan yang didapat tentang 
kesehatan. Pengetahuan sangat erat kaitannya dengan pendidikan di mana diharapkan seseorang dengan pendidikan tinggi, maka orang tersebut akan semakin luas pula pengetahuannya.

\section{Pengetahuan Ibu Rumah Tangga tentang Penularan Infeksi HIV/AIDS}

Berdasarkan tabel 5 didapatkan data bahwa gambaran pengetahuan ibu rumah tangga di Wilayah Haji Ungar RT.001/RW.III Tanjungpinang tentang penularan infeksi HIV/AIDS yaitu baik (91\%). Hal ini juga dipengaruhi oleh tingkat pendidikan ibu rumah tangga.

\section{Pengetahuan Ibu Rumah Tangga tentang Tanda dan Gejala Infeksi HIV/AIDS}

Berdasarkan tabel 6 didapatkan data bahwa gambaran pengetahuan ibu rumah tangga di Wilayah Haji Ungar RT.001/RW.III Tanjungpinang tentang tanda dan gejala infeksi HIV/AIDS yaitu kurang $(51 \%)$. Hal ini dapat disebabkan oleh faktor informasi yang didapatkan terbatas, di mana sesuai dengan salah satu teori menyebutkan selain tingkat pendidikan faktor kurangnya informasi dapat mempengaruhi pengetahuan.

Menurut Notoadmodjo (2010), faktor-faktor yang dapat mempengaruhi pengetahuan antara lain adalah Informasi yang diperoleh baik dari pendidikan formal maupun non formal dapat memberikan pengaruh jangka pendek (immediate impact) sehingga menghasilkan perubahan atau peningkatan pengetahuan. Majunya teknologi akan tersedia bermacammacam media massa yang dapat mempengaruhi pengetahuan masyarakat tentang inovasi baru. Sebagai sarana komunikasi, berbagai bentuk media massa seperti televisi, radio, surat kabar, majalah, dan lain-lain mempunyai pengaruh besar terhadap pembentukan opini dan kepercayaan orang. Dalam penyampaian informasi sebagai tugas pokoknya, media massa membawa pula pesan-pesan yang berisi sugesti yang dapat mengarahkan opini seseorang. Adanya informasi baru mengenai sesuatu hal memberikan landasan kognitif baru bagi terbentuknya pengetahuan terhadap hal tersebut.

\section{Pengetahuan Ibu Rumah Tangga Tentang Upaya yang Dilakukan Bila Mengalami Tanda dan Gejala AIDS}

Berdasarkan tabel 7 didapatkan data bahwa gambaran pengetahuan ibu rumah tangga di Wilayah
Haji Ungar RT.001/RW.III Tanjungpinang tentang upaya yang dilakukan bila mengalami tanda dan gejala AIDS yaitu baik (92\%). Hal ini dapat disebabkan oleh faktor pengalaman dan menjadi kebiasaan dalam menangani suatu penyakit, dimana ibu yang biasanya jika didapat tanda dan gejala dari suatu penyakit, maka ibu langsung memeriksakan tanda dan gejala dari suatu penyakit tersebut. Sesuai dengan salah satu teori menyebutkan selain tingkat pendidikan dan informasi, pengalaman juga dapat mempengaruhi pengetahuan.

Menurut Notoadmodjo (2010), faktor-faktor yang dapat mempengaruhi pengetahuan antara lain adalah pengalaman. Pengalaman sebagai sumber penagetahuan adalah suatu cara untuk memperoleh kebenaran pengetahuan dengan cara mengulang kembali pengetahuan yang diperoleh dalam memecahkan masalah yang dihadapi masa lalu. Pengalaman belajar dalam bekerja yang dikembangkan memberikan pengetahuan dan keterampilan professional serta pengalaman belajar selama bekerja akan dapat mengembangkan kemampuan mengambil keputusan yang merupakan menifestasi dari keterpaduan menalar secara ilmiah dan etik yang bertolak dari masalah nyata dalam bidang kerjanya.

\section{Pengetahuan Ibu Rumah Tangga tentang Pencegahan Penularan Infeksi HIV/AIDS}

Berdasarkan tabel 8 didapatkan data bahwa gambaran pengetahuan ibu rumah tangga di Wilayah Haji Ungar RT.001/RW.III Tanjungpinang tentang pencegahan penularan infeksi HIV/AIDS yaitu baik (99\%). Hal ini dapat disebabkan oleh faktor sosial budaya di mana bagi ibu mencegah lebih baik dari pada mengobati. Sesuai dengan teori, faktor sosial budaya juga dapat mempengaruhi pengetahuan.

Menurut Notoadmodjo (2010), faktor-faktor yang dapat mempengaruhi pengetahuan adalah faktor sosial budaya yaitu kebiasaan dan tradisi yang dilakukan orang-orang tanpa melalui penalaran apakah yang dilakukan baik atau buruk. Dengan demikian seseorang akan bertambah pengetahuannya walaupun tidak melakukan. Status ekonomi seseorang juga akan menentukan tersedianya suatu fasilitas yang diperlukan untuk kegiatan tertentu, sehingga status sosial ekonomi ini akan memepengaruhi pengetahuan seseorang. 


\section{Pengetahuan Ibu Rumah Tangga Tentang Tanda dan Gejala Infeksi HIV/AIDS Wilayah Haji Ungar RT.001/RW.III Tanjungpinang}

Berdasarkan hasil penelitian pada tabel 9 didapatkan data dari 30 responden bahwa pengetahuan ibu rumah tangga di wilayah haji ungar RT.001/ RW.III terhadap tanda dan gejala infeksi HIV/AIDS yaitu baik (86\%). Menurut Budiman (2011), pengetahuan adalah pengenalan akan sesuatu, atau apa yang akan dipelajari. Hal ini menunjukkan pengetahuan yang dimiliki ibu rumah tangga di wilayah haji ungar RT.001/RW.III yaitu baik, dapat dikarenakan pengenalan yang baik terhadap permasalahan tersebut. Tingkat pendidikan, pengalaman, ataupun sosial budaya yang baik terhadap permasalahan tersebut akan membuat ibu rumah tangga dapat mengenali masalah tersebut.

Menurut Notoadmodjo (2012), pengetahuan adalah hasil tahu dari manusia, yang sekadar menjawab pertanyaan "what", misalnya apa air, apa manusia, apa alam, dan sebagainya. Faktor-faktor yang dapat mempengaruhi pengetahuan antara lain tingkat pendidikan, informasi, budaya, pengalaman, dan sosial ekonomi. Ibu rumah tangga yang berpengetahuan baik karena ibu rumah tangga tersebut memiliki pengetahuan dari pendidikan dan informasi tentang penyakit HIV/AIDS. Sehingga mampu menjawab permasalahan mengenai pengertian HIV/ AIDS, penularan infeksi HIV/AIDS, tanda dan gejala infeksi HIV/AIDS, upaya yang dilakukan bila mengalami tanda dan gejala AIDS, serta pencegahan terhadap penularan virus HIV/AIDS tersebut.

Menurut Notoadmodjo (2010), pengetahuan adalah hasil penginderaan manusia, atau hasil tahu seseorang terhadap objek melalui indra yang dimilikinya (mata, hidung, telinga, dan sebagainya). Dengan sendirinya pada waktu penginderaan sehingga menghasilkan pengetahuan tersebut sangat dipengaruhi oleh intensitas perhatian dan persepsi terhadap objek.Hal ini menunjukkan pengetahuan yang dimiliki ibu rumah tangga dapat dikarenakan pengenalan ataupun penginderaan yang baik terhadap permasalahan tersebut.

\section{SIMPULAN DAN SARAN}

\section{Simpulan}

Berdasarkan hasil analisis dan pembahasan yang dikemukakan makadapat disimpullkan bahwa:

Gambaran pengetahuan ibu rumah tangga di Wilayah Haji Ungar RT.001/RW.III Tanjungpinang tentang Pengertian HIV/AIDS yaitu baik (97\%). Hal ini disebabkan karena faktor tingkat pendidikan dari ibu rumah tangga yang terbanyak pendidikan terakhirnya adalah tingkat SMA sebanyak 18 orang $(60 \%)$.

Gambaran pengetahuan ibu rumah tangga di Wilayah Haji Ungar RT.001/RW.III Tanjungpinang tentang Penularan Infeksi HIV/AIDS yaitu baik (91\%). Hal ini juga dipengaruhi oleh tingkat pendidikan ibu rumah tangga.

Gambaran pengetahuan ibu rumah tangga di Wilayah Haji Ungar RT.001/RW.III Tanjungpinang tentang Tanda dan Gejala Infeksi HIV/AIDS yaitu kurang $(51 \%)$. Hal ini dapat disebabkan oleh faktor informasi yang didapatkan terbatas, dimana sesuai dengan salah satu teori menyebutkan selain tingkat pendidikan faktor kurangnya informasi dapat mempengaruhi pengetahuan.

Gambaran pengetahuan ibu rumah tangga di Wilayah Haji Ungar RT.001/RW.III Tanjungpinang tentang Upaya yang Dilakukan Bila Mengalami Tanda dan Gejala AIDS yaitu baik (92\%). Hal ini dapat disebabkan oleh faktor pengalaman dan menjadi kebiasaan ibu dalam menangani suatu penyakit.

Gambaran pengetahuan ibu rumah tangga di Wilayah Haji Ungar RT.001/RW.III Tanjungpinang tentang Pencegahan Penularan Infeksi HIV/AIDS yaitu baik (99\%). Hal ini dapat disebabkan oleh faktor sosial budaya dimana bagi ibu mencegah lebih baik dari pada mengobati.

Dari 30 responden didapat bahwa pengetahuan ibu rumah tangga di wilayah haji ungar RT.001/ RW.III terhadap tanda dan gejala infeksi HIV/ AIDSdi Wilayah Haji Ungar Kelurahan Tanjung Ayun Sakti Kecamatan Bukit Bestari yaitu baik $(86 \%)$.

\section{Saran}

Berdasarkan hasil dan kesimpulan penelitian saran yang dapat dipertimbangkan adalah:

Untuk ibu rumah tangga di wilayah haji ungar sebagai tempat penelitian, hasil penelitian ini disarankan untuk digunakan sebagai bahan kajian untuk meningkatkan pengetahuan guna meningkatkan kesehatan dan mencegah terjadinya penularan infeksi virus HIV/AIDS.

Untuk ibu rumah tangga disarankan untuk dapat meningkatkan pengetahuan dan kesehatan terutama kesehatan mengenai sistem kekebalan tubuh. Ibu juga disarankan untuk melakukan pengecekan kesehatan di fasilitas kesehatan yang tersedia. 
Untuk puskesmas, disarankan untuk dapat meningkatkan pengetahuan ibu rumah tangga tentang tanda dan gejala infeksi HIV/AIDS guna meningkatkan pengetahuan ibu dan mencegah terjadinya penyebaran infeksi virus HIV/AIDS, serta agar ibu tau mengenai upaya apa yang akan dilakukan bila mengallami tanda dan gejala AIDS dengan cara promosi kesehatan.

Untuk penelitian lebih lanjut, penelitian ini dapat digunakan oleh peneliti selanjutnya bagi penelitian lanjutan yang merupakan pengembangan dari penelitian ini. Disarankan untuk dapat meneliti tentang gambaran sikap ibu rumah tangga tentang upaya pencegahan infeksi HIV/AIDS di rumah tangga.

\section{DAFTAR RUJUKAN}

Hidayat, A.A.A. 2008. Riset Keperawatan dan Teknik Penulisan Ilmiah. Jakarta: Salemba Medika.

Hutapea, R. 2011. AIDS \& PMS dan Pemerkosaan. Jakarta: Rineka Cipta.
Notoatmodjo, S. 2010. Ilmu Perilaku Kesehatan. Jakarta: Rineka Cipta.

2012. Metodologi Penelitian Kesehatan. Jakarta: Rineka Cipta

Nursalam. 2008. Konsep dan Penerapan Metodologi Penelitian Ilmu Keperawatan. Jakarta: Salemba Medika.

Nursalam \& Dian, K. 2007. Asuhan Keperawatan pada HIV/AIDS. Edisi1. Jakarta: Salemba Medika.

Roidatunisa. 2009. "Peran World Health Organization (WHO) melalui Global Programme on AIDS dalam Menangani Kasus HIV/AIDS di Indonesia”. [07/01/14].

Wicaksana, J.F.P., \& Kusumawati, Y. 2009. "Pengetahuan Tentang HIV/AIDS dan Voluntary Counseling". Jurnal Kedokteran Indonesia Vol.1/No.2. Melalui http://elib.unikom.ac.id/files/disk1/394/ jbptunikompp-gdl-roidatunis-19690-1-pdfroid8.pdf [07/01/14]

Widoyono, M.P.H. 2008. Penyakit Tropis Epidemiologi, Penularan, Pencegahan, dan Pemberantasannya. Jakarta: Penerbit Erlangga. 